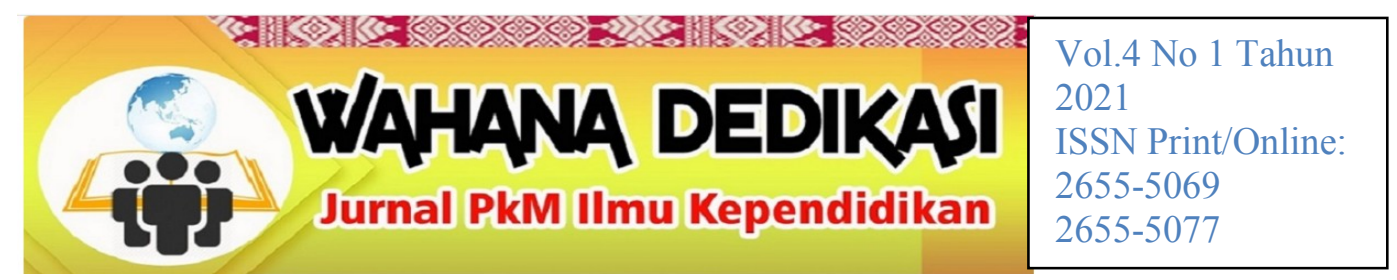

\title{
INOVASI PEMBELAJARAN E-LEARNING DALAM MENGHADAPI NEW NORMAL DI SMK NEGERI 1 LAWANG WETAN
}

\author{
Sulistiawati ${ }^{1}$, Lukman Hakim ${ }^{2}$, Patricia H.M. Lubis ${ }^{3}$, Rita Sulistyowati ${ }^{4}$, \\ Sugiarti ${ }^{5}$, Lefudin ${ }^{6}$ \\ Program Studi Pendidikan FisikaUniversitas PGRI Palembang \\ 1'sulistiawati@univpgri-palembang.ac.id, ${ }^{2}$ lukmanhakim1976@gmail.com, \\ 3patricialubis@gmail.com, ${ }^{4}$ ritarahman08@gmail.com, ${ }^{5}$ sugiartialatiq@gmail.com, \\ ${ }^{6}$ lefudinlefi@gmail.com
}

\begin{abstract}
Abstrak
Kondisi pandemi Covid-19 ini menciptakan kondisi yang ada seolah"dipaksa" bertransformasi dan beradaptasi secara drastis dalam melakukan pembelajaran dari rumah melalui media daring (online). Berbagai aplikasi media pembelajaran pun sudah tersedia, baik pemerintah maupun swasta. Pemerintah mengeluarkan Surat Edaran Menteri Pendidikan dan Kebudayaan Nomor 9/2018 tentang Pemanfaatan Rumah Belajar. Pihak swasta pun menyuguhkan bimbingan belajar online seperti ruang guru, Zenius, Klassku, Kahoot, dan lainnya. Guru dituntut untuk lebih kreatif dan berinovatif dalam melaksanakan pembelajaran di sekolah. Oleh karena itu, perlu diadakannya suatu pelatihan pembelajaran kepada guruguru untuk memotivasi dalam melaksanakan kewajibannya sebagai pendidik. Penyuluhan tersebut bertemakan "Inovasi Pembelajaran e-learning dalam menghadapi New Normal di SMK Negeri 1 Lawang Wetan MusiBanyuasin". Peserta adalah guru SMK 1 Lawang Kidul Musi Banyuasin yang berjumlah 36 orang. Materi yang disajikan cukup antusias ditanggapi peserta pelatihan. Hal ini bias dilihat dari pertanyaan yang diajukan peserta dan hasil angket yang diberikan. Angket menggunakan skala likert dengan rata-rata keseluruhan 4,47. Hal ini berarti sebagian besar peserta sangat setuju dengan penyuluhan dan pelatihan yang diberikan. Pesan dan kesan yang disajikan peserta juga sangat positif.
\end{abstract}

Kata Kunci: Kreatifitas,Inovasi, Pengabdian kepada masyarakat.

\begin{abstract}
The conditions of the Covid-19 pandemic created conditions that seemed to be "forced" to transform and adapt drastically in learning from home through online media (on line). Various learning media applications are already available, both government and private. The government issued a Circular of the Minister of Education and Culture Number 9/2018 concerning the Utilization of Learning Houses. The private sector also provides online tutoring such as the teacher room, Zenius, Klassku, Kahoot, and others. Teachers are required to be more creative and innovative in implementing learning in schools. Therefore, it is necessary to hold a learning training for teachers to motivate them to carry out their obligations as educators. The counseling had the theme "Innovation of elearning in Facing the New Normal at SMK Negeri 1 Lawang Wetan Musi Banyuasin". Participants were 36 teachers of SMK 1 Lawang Kidul Musi




\section{WAHANA DEDIKASI}

Banyuasin. The material presented was responded enthusiastically by the training participants. This can be seen from the questions asked by the participants and the results of the questionnaires given. The questionnaire used a Likert scale with an overall average of 4.47 . This means that most participants strongly agree with the education and training provided. The messages and impressions presented by the participants were also very positive.

Keywords: Creativity, Inovation, Community service.

Artikel disetujui tanggal: 30-05-2021

Corresponden Author:Sulistiawati e-mail: sulistiawati@univpgri-palembang.ac.id

DOI: $h$ ttp://dx.doi.org/10.31851/dedikasi.v4i21.5274doi

\section{PENDAHULUAN}

Kementerian Pendidikan dan Kebudayaan

(Kemendikbud) menerbitkan beberapa surat edaran terkait pencegahan dan penanganan Covid-19. Pertama, Surat Edaran Nomor 2 Tahun 2020 tentang Pencegahan dan Penanganan Covid19 di Lingkungan Kemendikbud. Kedua, Surat Edaran Nomor 3 Tahun 2020 tentang Pencegahan Covid-19 pada Satuan Pendidikan. Ketiga, Surat Edaran Nomor 4 Tahun 2020 tentang Pelaksanaan Kebijakan Pendidikan dalam Masa Darurat Penyebaran Coronavirus Disease (Covid-19) yang antara lain memuat arahan tentang proses belajar dari rumah (Aprianto et al, 2021).

Untuk mengurangi dan menekan penyebaran Covid-19, berbagai wilayah di Indonesia menetapkan kebijakan belajar dari rumah. Salah satu pertimbangannya adalah sekolah merupakan tempat berkumpul dimana setiap harinya terjadi aktivitas interaksi dan berkumpulnya antara siswa dan guru. Oleh karena itu seluruh wilayah pada zona orange maupun merah, baik itu pada jenjang pendidikan mulai dari jenjang prasekolah hingga pendidikan tinggi, baik itu pada sekolah negeri maupun swasta ditetapkan untuk menggunakan system belajar online.

Era New Normal adalah era kenormalan baru setelah penularan Covid dianggap berkurang. Pemanfaatan teknologi digital dalam proses pembelajaran, penyelesaian berbagai tugas, dan peningkatan kompetensi guru, tak bisa lepas dari arus perkembangan informasi dan teknologi. Menghadapi tantangan tersebut, guru sebagai garda terdepan dalam dunia pendidikan dituntut untuk siap berubah dan beradaptasi. Peran guru tidak akan tergantikan oleh mesin secanggih apa pun. Sebab, guru diperlukan untuk membentuk karakter anak bangsa dengan budi pekerti, toleransi, dan nilai kebaikan. Para guru juga mampu menumbuhkan empati sosial, membangun imajinasi dan kreativitas, serta mengokohkan semangat persatuan dan kesatuan bangsa (Utomo, 2019).

E-learning adalah teknologi informasi dan komunikasi untuk 


\section{WAHANA DEDIKASI}

mengaktifkan siswa untuk belajar kapanpun dan dimanapun (Dahiya,2012). Pembelajaran elektronik atau e-learning telah dimulai pada tahun 1970-an (Waller and Wilson, 2001). Berbagai istilah digunakan untuk mengemukakan pendapat/gagasan tentang pembelajaran elektronik, antara lain adalah: online learning, internetenabled learning, virtual learning, atau web-based learning. Ada 3 (tiga) hal penting sebagai persyaratan kegiatan belajar elektronik (elearning), yaitu: (a) kegiatan pembelajaran dilakukan melalui pemanfaatan jaringan, dalam hal ini dibatasi pada penggunaan internet, (b) tersedianya dukungan layanan belajar yang dapat dimanfaatkan oleh peserta belajar, misalnya External Harddisk, Flaskdisk, CD-ROM, atau bahan cetak, dan (c) tersedianya dukungan layanan tutor yang dapat membantu peserta belajar apabila mengalami kesulitan. Di samping ketiga persyaratan tersebut di atas masih dapat ditambahkan persyaratan lainnya, seperti adanya: (a) lembaga yang menyelenggarakan dan mengelola kegiatan e-learning, (b) sikap positif dari peserta didik dan tenaga kependidikan terhadap teknologi komputer dan internet, (c) rancangan sistem pembelajaran yang dapat dipelajari dan diketahui oleh setiap peserta belajar, (d) sistem evaluasi terhadap kemajuan atau perkembanganbelajar peserta belajar, dan (e) mekanisme umpan balik yang dikembangkan oleh lembaga penyelenggara.

Dalam penerapan teknologi seperti penggunaan e-learning, perlu diformulasikan strategi yang jelas sebagai acuan. Penyusunan strategi e-learning seperti disampaikan Empy (2005) berguna untuk memperjelas tujuan pelatihan atau pendidikan yang ingin dicapai (2) mengetahui sumber daya yang dibutuhkan (3) membuat semua pihak yang terlibat untuk tetap mengacu pada tujuan yang sama. (4) mengetahui

pengukuran keberhasilan.

\section{BAHAN DAN METODE}

Kegiatan pengabdian ini dilaksanakan pada februari 2021 dengan beberapa metode sebagai berikut:

1. Metode ceramah dan tutorial digunakan untuk memberikan penjelasan tentang materi pelatihan yang akan disampaikan.

2. Metode tanya jawab digunakan untuk menggali pemahaman terhadap materi yang akan diberikan.

3. Evaluasi digunakan untuk mengukur kinerja selama kegiatan PKM, evaluasi produk yang dihasilkan dan angket kepuasan selama kegiatan berlangsung. 
Evaluasi akan dilakukan dalam bentuk angket. Angket menggunakan skala Likert, dimana pointer besar adalah 5 dan terkecil adalah 1 . Pertanyaan angket yang diajukan adalah sebagai berikut :

1. Materi yang disajikan terorganisir dengan baik

2. Materi sangat relevan dan sesuai dengan yang saya harapkan

3. Dengan materi ini akan memudahkan saya memberikan pemahaman kepada rekan kerja untuk bersama-sama memperbaiki /mengembangkan

perancangan pembelajaran daring.

4. Pemateri sangat memahami materi yang dipresentasikan

5. Alokasi waktu penyampaian materi sudah mencukupi

6. Pemateri mempresentasikan isi materi dengan baik dan mudah dimengerti

7. Alokasi waktu untuk diskusi mencukupi untuk menambah / memperkuat materi

8. Pemateri memberikan jawaban terhadap pertanyaan peserta dengan baik

9. Secara keseluruhan diskusi / Tanya jawab telah sangat membantu meningkatkan pemahaman peserta
10. Kelayakan media zoom sebagai media penyuluhan memadai

11. Tidak ada kendala teknis untuk komunikasi antara pemateri dan peserta melalui media zoom dapat berjalan dengan baik

12. Pesan dan kesan setelah mengikuti rangkaian acara penyuluhan

\section{HASIL DAN PEMBAHASAN}

Dari hasil angket ini terlihat bahwa rata-rata nilai angket adalah 4,47 (sangat setuju). Artinya sebagian besar peserta pelatihan merespon dengan baik pelatihan ini. Menurut mereka materi yang disajikan terorganisir dengan baik, sangat relevan dan sesuai dengan yang diharapkan. Materi yang diberikan sudah dianggap mencukupi untuk mampu menyusun pembelajaran daring dan bias berbagi kepada teman sejawat untuk bersama-sama memperbaiki/ mengembangkan perancangan pembelajaran daring. Pemateri dianggap sangat memahami materi yang dipresentasikan dan mempresentasikan materi dengan baik serta menjawab pertanyaan peserta dengan baik. Pemahaman peserta meningkat alokasi waktu yang diberikan sudah mencukupi dan zoom yang digunakan sudah cukup 
layak serta tidak ada kendala yang berarti.

Pesan dan kesan yang diberikan cukup baik Mereka mendapat pengalaman pembelajaran yang baik, bermanfaat dan menambah wawasan. Mereka juga termotivasi untuk mengembangkan pembelajaran online lainnya. Harapan mereka untuk dikembangkan lebih baik lagi.

\section{KESIMPULAN}

Kesimpulan kegiatan PKM di SMK Lawang Wetan Kabuaten Musi Banyuasin adalah sebagai berikut:

1. Sebagian besar peserta pelatihan merespon dengan baik pelatihan ini.

2. Pemateri dianggap sangat memahami materi yang dipresentasikan dan mempresentasikan materi dengan baik serta menjawab pertanyaan peserta dengan baik.

3. Pesan dan kesan yang diberikan cukup baik

\section{DAFTAR PUSTAKA}

Apriyanto, M., Oklianda, A., Putra, D. D., \& Warmi, A. (2021, February). Student Responses During Online Learning in the Covid-19 Pandemic Period. In Journal of Physics:
Conference Series (Vol. 1764, No. 1, p. 012125). IOP Publishing.

Brown-Martin, G. (2017). Education and the fourth industrial revolution. Report for Group Media TFO. https:// www.groupemediatfo.org/wpc ontent/uploads/2017/12/FINA L.

Dahiya, S., Jaggi, S., Chaturvedi, K.K., Bhardwaj, A., Goyal, R.C. and Varghese, C., 2016. An eLearning System for Agricultural Education. Indian Research Journal of Extension Education, 12(3), pp.132-135. Empy Effendi, Hartono Zuang .2005. E-learning Konsep dan Aplikasi. Jakarta: Penerbit Andi Yogyakarta.

Hartanto, A. A., \& Purbo, O. W. (2002). Buku pintar internet teknologi e-learning berbasis PHP dan MySQL. Jakarta: Penerbit PT Elex Media Komputindo Kelompok Gramedia.

Nugroho, W. A. (2007). [online] Available FTP: http://www.ilmukomputer.co m. Tanggal akses: 16 Januari 2020.

Utomo, Susilo S. (2019). Guru di Era Revolusi Industri 4.0. [Online]:

http://eprints.uny.ac.id/65069/ 1/GURU\%20DI\%20ERA $\% 20$ 
Sulistiawati, Lukman Hakim, Patricia H.M. Lubis, Rita Sulistyowati, Sugiarti, Lefudin (2021)

Inovasi Pembelajaran E-Learning Menghadapi New Normal Di SMK Negeri 1 Lawang Wetan

\section{WAHANA DEDIKASI}

$\underline{\text { REVOLUSI\%20INDUSTRI\% }}$

204.0.pdf

Waller, V. and Wilson, J. 2001. A definition for e-learning. TheODL QC Newsletter, pp. $1-2$. 